\title{
CHANGES IN ADMINISTRATIVE STATUS AND URBAN BUILT FORMS OF THE TOWN CENTRE OF BERETTYÓÚJFALU AFTER THE SECOND WORLD WAR
}

\author{
ZOLTÁN MEGYERI-PÁLFFI*® ${ }^{*}$ KATALIN MARÓTZY** \\ "PhD in Law. PhD student. Department of History of Architecture and Monument Preservation, \\ BME K II. 82, Müegyetem rkp. 3, H-1111 Budapest, Hungary. E-mail: mpzoltan@gmail.com \\ ${ }^{* *} \mathrm{PhD}$, assistant professor. Department of History of Architecture and Monument Preservation, \\ BME K II. 82, Múegyetem rkp. 3, H-1111 Budapest, Hungary. E-mail: mkata@eptort.bme.hu
}

After the Second World War, Hungary adopted the so-called Soviet model, which gave rise to significant changes in the state organisation. "Centralisation" and "democratic centralism" are the keywords which described the operation of government and local bodies in the four decades between 1945 and 1990.

Through the change of the townscape of one settlement, this study throws light on how the change in administrative status and the centrally determined settlement policy affected urban development in Hungary, similarly to other former socialist states.

Our highlighted example is Berettyóújfalu, whose administrative status changed from period to period in its $19-20^{\text {th }}$ century history. Today, Berettyóújfalu's townscape is basically determined by three architectural periods: the era of the Austro-Hungarian Monarchy (1867-1918), the period between the two world wars (1918-1944) and the age of state socialism (1949-1989). Out of these periods, the third one was the most significant, as the most important interventions into the townscape occurred at that time.

It seems that in Berettyóújfalu, the appearance of urban buildings has not been brought about by economic forces, but expressly by the change in the settlement's administrative status. It was this change that influenced the town's architectural character, which consists of two components: the official buildings and the residential building stock.

In the era of socialism, the construction of housing estates also falls into the category of public developments, as after the Second World War, the system of state organisation changed fundamentally. Local governments ceased to exist, their role was taken over by hierarchical councils. Consequently, urban policy and urban construction became central duties according to the socialist state concept.

The centrally developed industry and the resulting increase in the population was served by building housing blocks with system-building technology. These panel apartment blocks occupied the urban fabric that had been an integral part of the former townscape.

In this way, this changed townscape could become a kind of architectural reader on Central and Eastern European history and urban development of the 19-20 $0^{\text {th }}$ centuries.

Keywords: administrative status, townscape changing, Soviet model, city planning, urbanisation, Berettyóújfalu, Hungary

\footnotetext{
$\bowtie$ Corresponding author.
} 


\section{INTRODUCTION}

In the second half of the $20^{\text {th }}$ century, the identity of the towns of Central and Eastern Europe was considerably transformed due to historic changes occurring around two focal points. ${ }^{1}$ One of these goes back to the period between 1945 and 1950, while the other one took place around 1990.

Similarly to other states of the region, after the Second World War, Hungary adopted the so-called Soviet model, which gave rise to not only political, economic and social changes, but also to significant changes in the state organisation. "Centralisation" and "democratic centralism" are the keywords which described the operation of government and local bodies in the four decades between the two aforementioned dates.

The state socialism of these 40 years has not disappeared without trace: the townscape of the towns of the region still reflects the special approach and character of urban design of the age. There is an important factor in the background: the administrative state of the settlements and urban planning were closely interlocked in a centrally determined way.

Through the change of the townscape of one settlement, this study throws light on how the change in administrative status and the centrally determined settlement policy affected urban development in Hungary, similarly to other former socialist states.

Our highlighted example is Berettyóújfalu, whose administrative status changed from period to period in its $19-20^{\text {th }}$ century history. Centralised urban planning was a typical phenomenon in the socialist era, however, the effect of public administration on urban development is considered to be extreme in the history of the settlement. Consequently, we are going to examine the reasons for a characteristic current situation which derive from the recent past. For this work, we outline the changes in administrative situation of the settlement in the $19-20^{\text {th }}$ century. We interpret these changes as a period and compare them from the aspect of the type of administrative changes that have taken place and the new buildings that have appeared in the settlement in connection with the changes. Based on these, we scale the changes in the townscape. We present in detail the period considered to be the most significant in terms of changes in the building stock, and the decades following the Second World War. In terms of changes in the building stock, we consider the decades following the Second World War to be the most significant, so we present this period in detail.

Our study is based on period maps and law as primary sources, and in addition to these, we relied on the special literature in our examination.

\footnotetext{
${ }^{1}$ See e. g. Hirt 2007. 151-154; Kissfazekas 2015. 99-108; Węcławowicz 2016. 67-72; Iuga 2016; BallaBenkö-Durosaiye 2017. 192-194; Horák 2019; Tandarić-Watkins-D. Ives 2019; Among these countries, Yugoslavia had another political character. See Antonič-Lazarevič 2019.
} 


\section{THE EFFECT OF ADMINISTRATIVE CHANGES ON URBAN DESIGN/URBAN FORM}

Our fundamental question is the following: how did the modernisation of the administrative organisation influence the architectural identity of towns?

Our starting point can be found in professional literature: according to this principle, the administrative role of a given settlement drives the processes of urbanisation, therefore changes in the administrative organisation visibly affect the townscape. ${ }^{2}$

One of the tangible consequences of the change in administrative role is transformation into a seat. When a settlement, exceeding its responsibilities, also serves its environment regarding administrative and other services, its administrative status is going to change sooner or later, as well. According to the typical process, the given settlement becomes a district town, the centre of its closer geographical environment. If it is justified by certain factors, it can also become a county town, as it happened in the case of Berettyóújfalu.

In general, it can be stated that becoming a seat definitely promotes the development and urbanisation of a settlement. The extension of its administrative role, adds new institutions to the administrative functions of the settlement.

The local administration constitutes the internal administration of the town. According to present-day terminology, it is called municipal administration. On the other hand, the attribute "public" can be used with content related to central administration referring to regional bodies catering for the needs outside the settlement, as well. For example, such bodies include the district court, the land registry office or the tax office. Based on the above, a settlement that stands out in terms of public administration has multiple tasks: in addition to its local responsibilities, it takes a major part in fulfilling state administration tasks. ${ }^{3}$

In connection with the change of its administrative status, the settlement concerned also has new administrative responsibilities, which, of course, require space. The character of their location shows how the administrative organisation is physically differentiated in a given settlement, which, in many cases, is not reflected merely by the layout of rooms within the building, but also by the addition of a separate building. Basically, we can mention the headquarters (village/town/county halls), where administrative tasks are concentrated, as well as other administrative buildings having one function (e.g. tax office, state architecture office). Certain headquarters and administrative buildings determine their environment inadvertently. For example, a new town hall, provided that it is positioned well within the settlement, usually brings about the change of its environment, from landscape gardening to the adaptation of the surrounding buildings. Even one administrative building may induce the evolvement of a new city centre or subcentre. Such centres can develop into a kind of network, the intersections of roads which might accelerate urban develop-

\footnotetext{
${ }^{2}$ Beluszky-Győri 2005. 62-65; ESPON 2012. 7.

${ }^{3}$ Barta 2017. 53-78.
} 
ment and the change of the architectural character of the street view and the townscape.

A good example for this phenomenon is Berettyóújfalu, the town analysed in our study, as here, considering only the headquarters, we can find three spectacular elements: a new village hall was built in 1874-1875, a new county hall in 1925 and a new town hall in 1983. In addition, several subcentres evolved due to the new construction works arising from administrative changes. Over the past decades, some of these subcentres have proven to be more successful (e.g. the high sheriff's office (1910s); the officers' estate and the hospital (1920s); the party house (1976), while others have been less successful (e.g. the location of the new town hall in 1983).

\section{HISTORICAL BACKGROUND AND ORGANISATIONAL CHANGES AFTER THE SECOND WORLD WAR}

Despite the increasing influence of the government, local governments operated in settlements in the period of the Austro-Hungarian Monarchy and between the two world wars. However, in the decades after the Second World War, the settlements of Hungary were integrated into a hierarchical system. Immediately after the war, the state was reorganised still on the basis of democratic principles. In 1945, parliamentary elections were held. The legislation was convened and the government was formed based on the results. During the coalitional period, a gradual political and ideological change of direction was taking place. By 1948, the so-called Soviet model had been adopted by Hungary, as well. The organisation of public administration was not unaffected either. The constitution of the time, Act XX of 1949, which was based on the Soviet Constitution of 1936, defined councils as the local bodies of the Hungarian People's Republic. It was only the declaration of the establishment of the new administrative system. The organisation was regulated by the law in Act I of 1950 for the first time.

The council system introduced by the aforementioned act fundamentally changed the Hungarian public administration. The former local governments were replaced by the councils at village, town, district and county level. The councils were hierarchically organised based on so-called democratic centralism. An important element of the system was that the superior bodies were entitled to directly interfere into the operation of inferior bodies. Moreover, under the law, in addition to its right to supervise and control higher council bodies, the Presidential Council of the People's Republic - the head of state's body - was entitled to amend and repeal the acts of lower bodies, infringing the provisions of the constitution and referring to the interests of the "working people". 4

Basically, the local organisations of the council system, which abolished the local governments, consisted of the council itself, which can be defined as a corporate

${ }^{4}$ Act I/1950. 55.§ 
body, and the executive committee belonging to it. Regarding operation, the latter two bodies were crucial.

The centralisation of local administrative bodies was observable in urban policy, as well. Following the Soviet model, urban development and regional development were centralised. This process culminated after 1949, when the preparation of the "First Five-Year Plan necessitated the coordination of the organisation of the people's economy and territorial organisation". ${ }^{5}$ In order to achieve this goal, the Institute of Spatial Planning was set up. Operating under the professional control of the Ministry of Construction, it was responsible for laying and elaborating the scientific ${ }^{6}$ foundation for the socialist urban policy. ${ }^{7}$ One of the results was the elaboration of the urban development concept, which classified towns and villages into three classes in terms of urban (municipal) planning. The first class included those settlements (towns, villages) which had to be developed above average already in the period of the First Five-Year Plan, as well as those in the territory of which bigger industrial or other investment projects had to be implemented. The settlements whose urban development had to be ensured, but which did not develop above the national average had to be classified into the second class. In the territory of these settlements institutions which provided not only for the local needs, but also for the needs of the district (agglomeration) had to be established. Other settlements had to be classified into the third class. ${ }^{8}$ The above-mentioned decrees were summarised in the higher-level Decree-Law No. 1/1951 on urban and municipal planning. Based on the principles laid down in this law, the settlements classified into the first category were favoured in the field of developments. $52.5 \%$ of the settlements with $85.6 \%$ of the country's population were listed into the aforementioned three categories. ${ }^{9}$

In 1963, a new study on planning was born, classifying the settlements into six basic regional categories. ${ }^{10}$ This study was already related to the Second Five-Year Plan, preparing the concept for the development of the network of settlements to be published in 1971. The accepted concept listed the settlements into a hierarchical order (national centre, tertiary centre, secondary centre, lower secondary centre, other municipalities), in connection with which they were categorised according to development goals. ${ }^{11}$ Beside the capital, the concept defined special high-level, high-level, partially high-level, intermediate-level and partially intermediate-level centres. These categories also defined the regional role of the settlements. Development funds were allocated to the role listed above based on centrally determined parameters. $^{12}$

\footnotetext{
${ }^{5}$ Hajdú 1990. 157.

${ }^{6}$ Jankovich 1950.

${ }^{7}$ Hajdú 1990. 158.

${ }^{8}$ Hajdú 1989. 88; Germuska 2002. 49-73.

${ }^{9}$ Hajdú 1990. 163.

${ }^{10}$ Gov. reg. 1022/1963. (IX. 21.); Gov. reg. 2022/1968. (VII. 13.)

${ }^{11}$ Gov. reg. 1007/1971. (III. 16.)

${ }^{12}$ Kissfazekas 2014. 92-132.
} 
The aforementioned change of urban policy and the introduction of the council system entailed regional reforms, as well. As a result, the territory of certain counties has fundamentally changed. ${ }^{13}$

Nonetheless, the centralised urban policy after the Second World War, as a specific administrative approach, typically generated (mainly industrial) developments which resulted in mass residential construction in the settlements. ${ }^{14}$ Consequently, the centres and urban fabric of several Hungarian settlements changed significantly, which led to the acceleration of urbanisation processes..$^{15}$

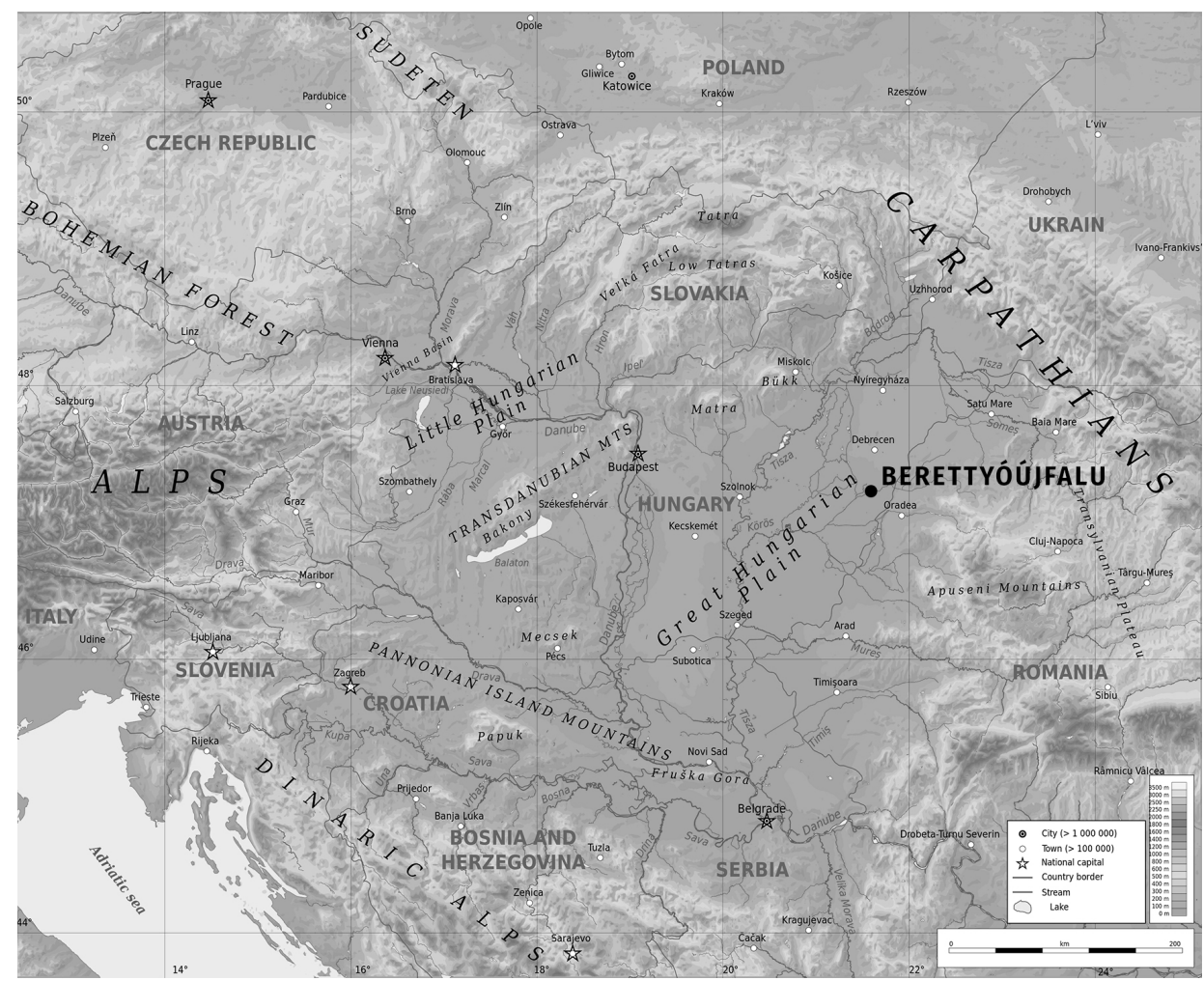

Figure 1. Geographical situation of Berettyóújfalu. Source: Pannonian Basin geographic map by Ikonact, CC. Edited by: Megyeri-Pálffi, Z.

${ }^{13}$ Decree 4343/1949. (XII. 14.) MT

${ }^{14}$ Bonta 1984. 20-22; Berey 1994; Körner-Nagy 2006. 37-38; Meggyesi 2006. 27; Benkő-Kissfazekas 2019. $13-15$.

${ }^{15}$ Benkő 2015; Kissfazekas 2017. 13. 


\section{BERETTYÓÚJFALU, THE SUBJECT OF OUR STUDY}

Berettyóújfalu, a settlement with a population of almost 17,000 is situated in Eastern Hungary, at the intersection of highways 42 and 47 and the meeting point of motorway M35, whose construction is in progress, and M4, as well as along the main railway connecting Budapest and Oradea (Fig. 1).

The town is located on the two banks of the Berettyó river. This location evolved in administrative sense when the village of Berettyószentmárton was attached to the municipality of Berettyóújfalu in 1970. Historically, it is a settlement formed from two villages, which had been in a very close relationship with each other for centuries.

The structural and urban form development of Berettyóújfalu as a settlement was primarily determined by the hydrographic conditions both in terms of the settlement core and its confines. The street network of the core of the settlement, between these watercourses, encompassed irregular plots that were constantly fragmenting over time. There were barn yards around the centre of the town. The town grew its barn yards only in the $19^{\text {th }}$ century, after the draining of watercourses, the appearance of the railway and the accompanying economic development removed the obstacles imposed by the water before the expansion of the settlement. However, the street network developed over the centuries has remained almost unchanged to this day.

The settlement expanded mainly to the east and south, but only very slowly, as the maps of military surveys illustrate (Fig. 2). Developing had already begun around

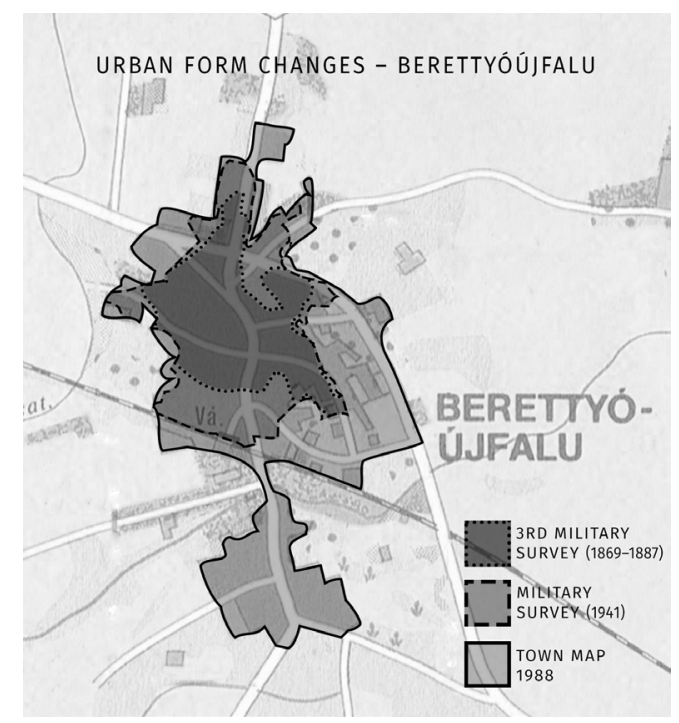

Figure 2. Urban form changes in Berettyóújfalu. This map is based on information of the Third Military Survey of the Habsburg Empire 1869-1887 (Hadtörténeti Intézet és Múzeum), Military Survey of Hungary 1941 (Hungarian Wars Archives) and the Town Map of Berettyóújfalu (Berettyóújfalu. Térkép. Kartográfiai Vállalat, Budapest, 1988). Edited by: Megyeri-Pálffi, Z. 


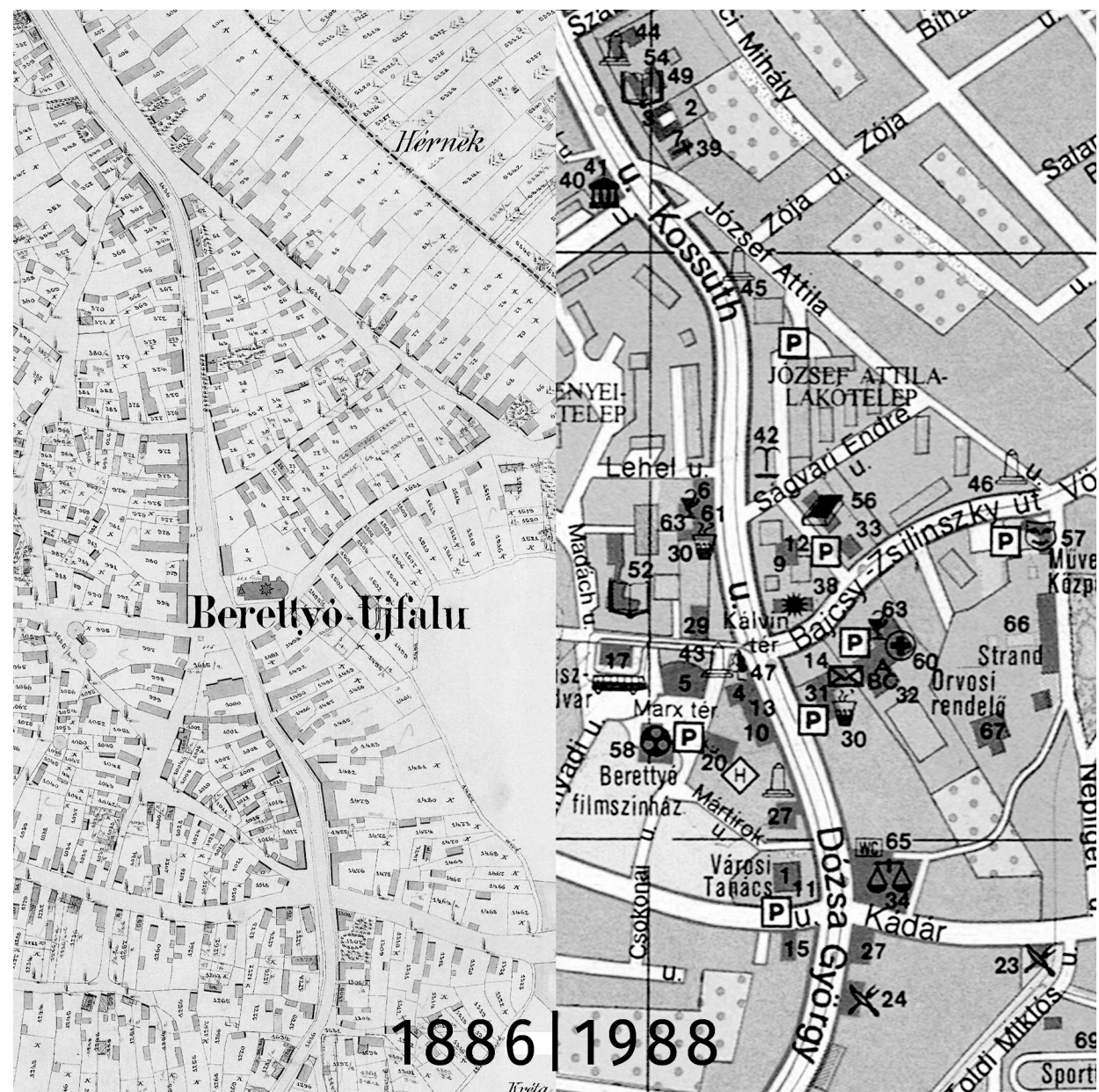

Figure 3. The map of the centre of Berettyóúffalu from 1886 and 1988. Source: Magyar Nemzeti Levéltár Országos Levéltára. S 78 Térképek (1786-1948) 054. téka - Berettyóújfalu, 48. section; Berettyóújfalu. Térkép. Kartográfiai Vállalat, Budapest, 1988. Edited by: Megyeri-Pálffi, Z.

the turn of the $20^{\text {th }}$ century, but only gained real momentum between the two world wars. In the second half of the $20^{\text {th }}$ century, the main east-south direction of expansion remained unchanged; the accession of the neighbouring settlement, Berettyószentmárton in 1970 meant territorial growth.

The change of the urban form is relevant to the objective of our study only in that it becomes visible how large the area affected by the local administration is and in what territorial context (settlement form, settlement fabric, architectural environment) the buildings that served the administration appeared. These buildings are discussed below. 
The highway 47 crossing the settlement constitutes the main street of the town from north to south. The architectural character of the town, which is defined by the imprint of three historical periods, is primarily determined by the buildings of the main street. The three historical periods are the era of the Austro-Hungarian Monarchy (1867-1918), the period between the two world wars (1918-1944) and the age of state socialism (1949-1989). The townscape changed considerably in all the three periods, which was mainly due to the change in the administrative status of the town. Our historical maps (from 1886 and 1988) illustrate the urban changes which occurred over more than 100 years (Fig. 3).

Due to the administrative reforms in the period of the Austro-Hungarian Monarchy, the settlement became a municipality, then a district seat. The typical administrative bodies of the age, such as the tax office, the district court (Fig. 4), which operated as a judicial body of first instance and the post office, appeared in the municipality. After having become a district seat, in addition to the previous offices, a chief district administrator, a district administrator, an assistant judge, a patrolman, a doctor and a veterinarian worked in the settlement, as well. In this period, separate buildings were raised for the chief district administrator, the notary and the tax office in the settlement. Moreover, already preparing for the change of the municipality's administrative role, a new multi-storey town hall was built in the centre in 1874-1875 (Fig. 5). The majority of administrative buildings built at the time became an integral part of the

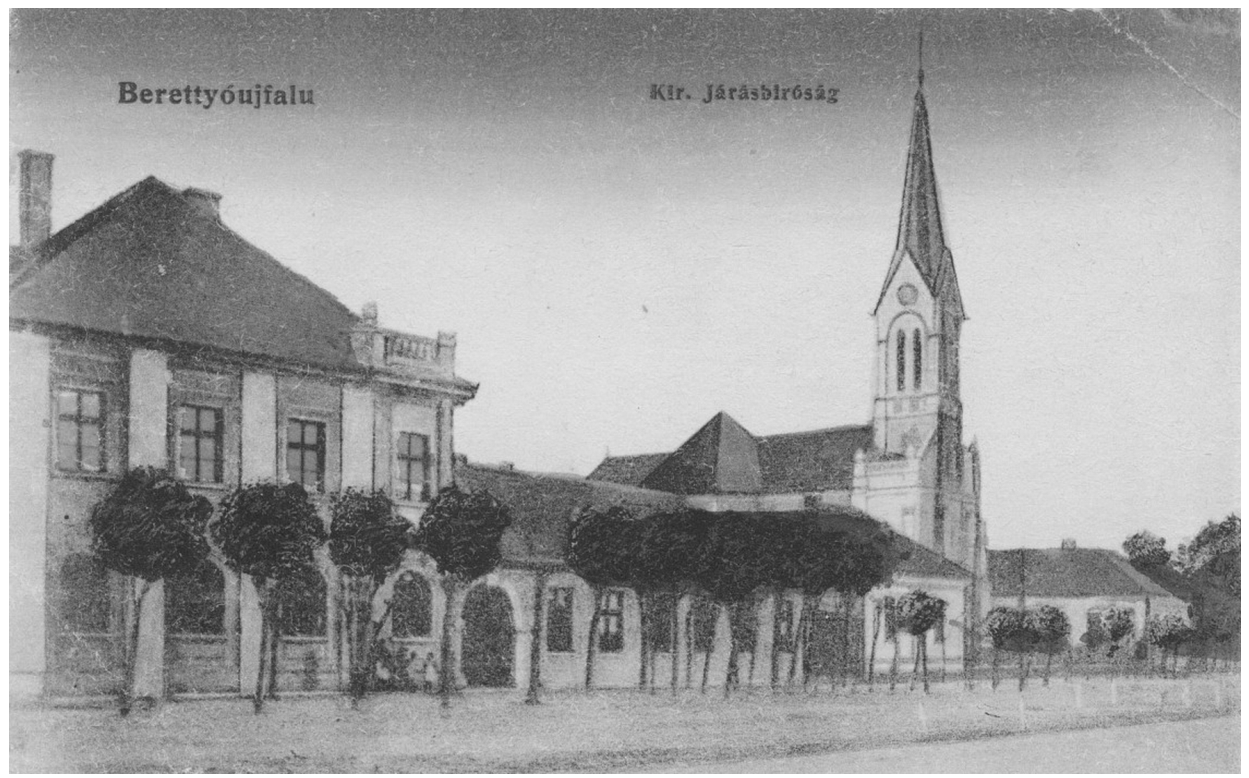

Figure 4. The district court and the Catholic church on a postcard from the early $20^{\text {th }}$ century. Source: Berettyóujfalu Topotéka, with the permission of Imre Békési (http://berettyoujfalu.topoteka.net), Bihari Múzeum, Berettyóújfalu 


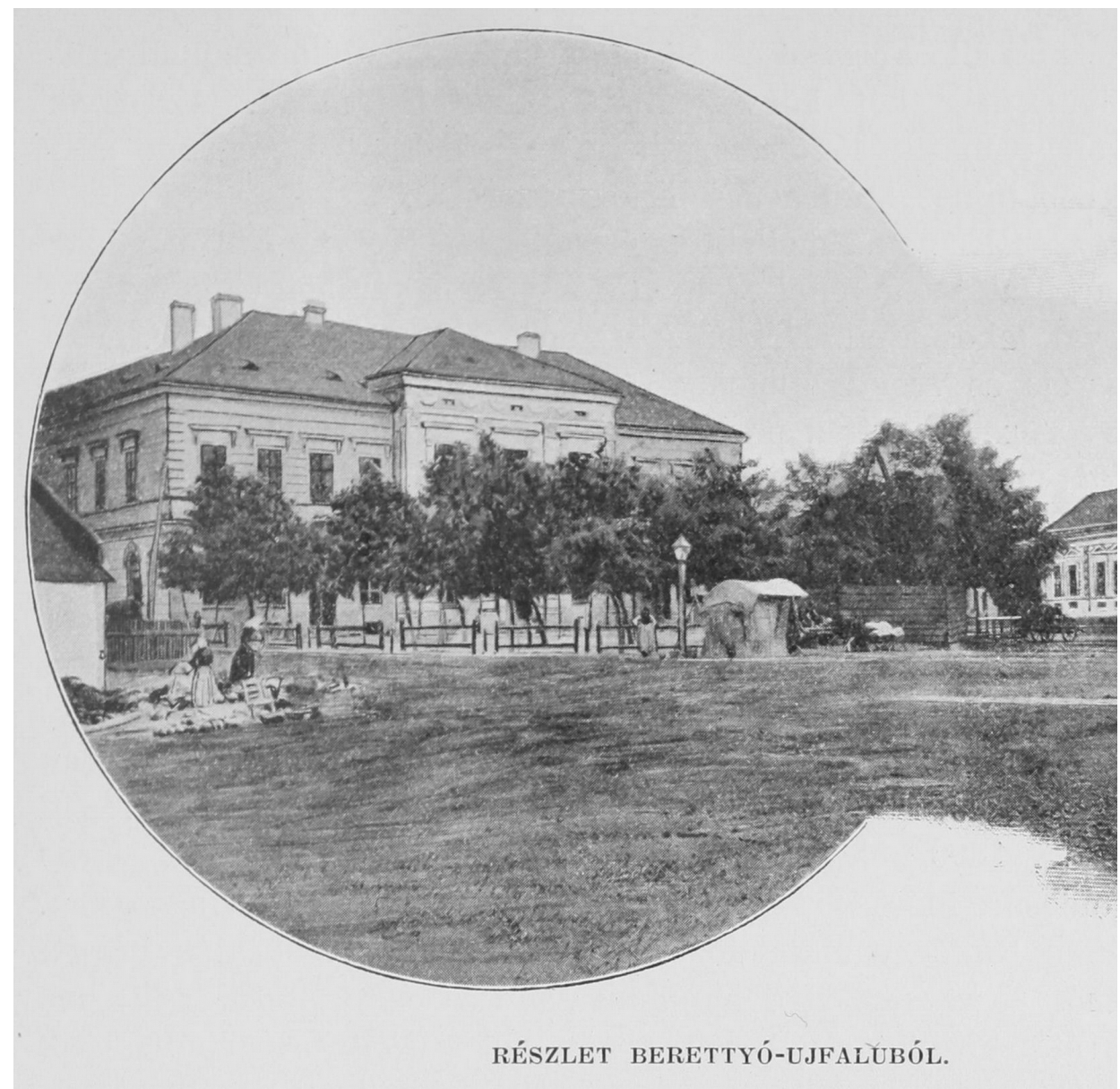

Figure 5. The village hall handed over in 1875. Source: Borovszky, Samu (ed.): Magyarország vármegyéi és városai. Bihar vármegye és Nagyvárad. Apollo Irodalmi Társaság, Budapest, 1901. 53.

townscape. Only their slightly larger size or perhaps more exquisite facade architecture distinguished them from their environment. Literally, only three buildings of this period stood out from the others: the new town hall, the railway station and the royal district court. ${ }^{16}$ All of them had several storeys, therefore they were stately public buildings among the single-floor houses. The new buildings' integration into the townscape is clearly indicated by the fact that these official buildings did not change the architecture and the structure of the town, they only laid the foundation for some urbanisation zones in the urban fabric. In this context, the only exception is the town

${ }^{16}$ Megyeri-Pálffi 2017. 57-67. 


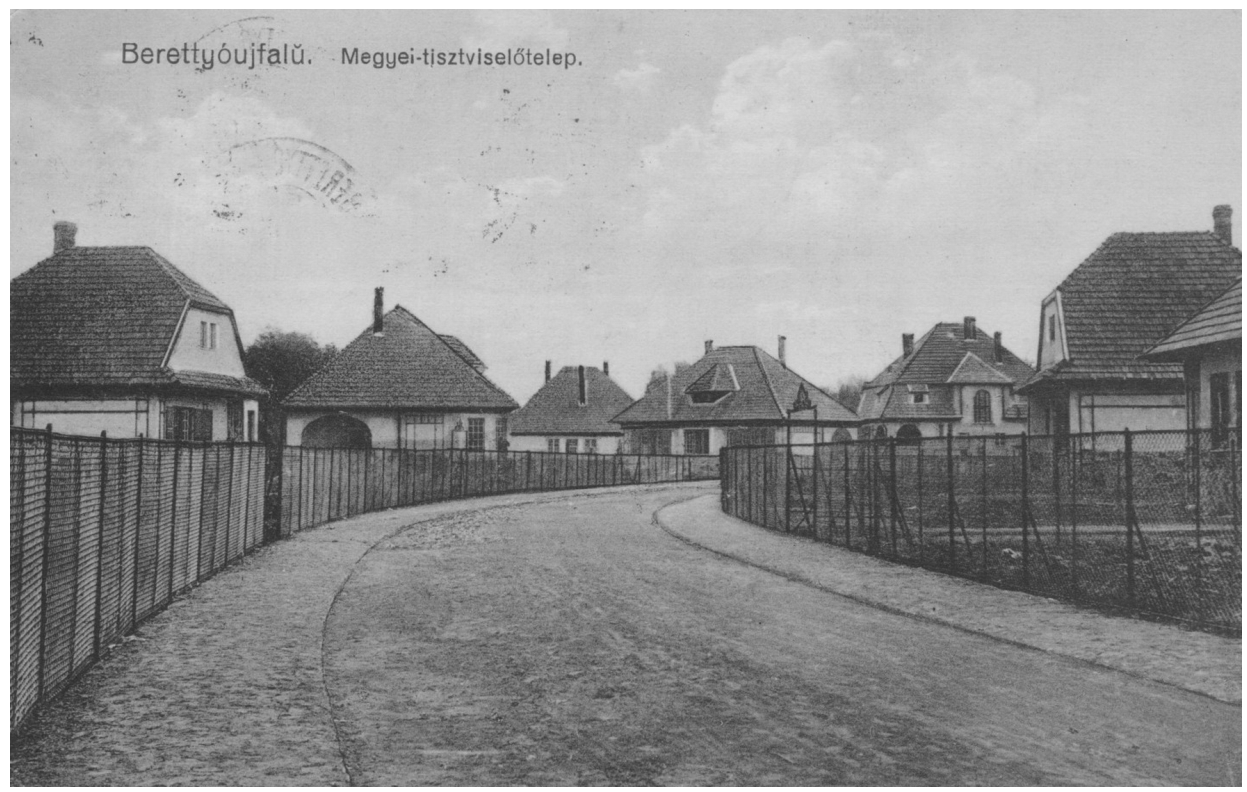

Figure 6. The Officers' Estate in Berettyóújfalu. Source: Berettyóújfalu Topotéka, with the permission of Imre Békési (http://berettyoujfalu.topoteka.net), Bihari Múzeum, Berettyóújfalu

hall, which had been finished by 1875 and built behind its predecessor. After its completion, the old town hall was demolished, ${ }^{17}$ resulting in the enlargement of the central marketplace. Moreover, at the very beginning of the $20^{\text {th }}$ century, after fairs had been moved into another place in the settlement, the marketplace became a city square. ${ }^{18}$

After the First World War, an important administrative status change took place in the life of Berettyóúfalu: The town became the seat of Bihar County, namely, the former county seat, Oradea, was annexed to Romania in the 1920 peace treaty that ended the war. Becoming the county seat which involved significant construction works, as the settlement already had county-level responsibilities. ${ }^{19}$ At the time, several elementary and secondary educational institutions, a hospital, a new post office were built in the town, as well as a new headquarters for the county's public administration was raised in the main street. Owing to the increase in the number of administrative tasks, more offices were needed, therefore a separate officers' estate (Fig. 6) was established near the future hospital, which seriously transformed the townscape. Before the First World war, there were hardly any urban multi-storey buildings in the settlement. At the same time, in this period, several such buildings appeared.

\footnotetext{
${ }^{17}$ N. N. 1875.

${ }^{18}$ Dankó 1981. 323-336.

${ }^{19}$ Sándor-Török 2011. 55.
} 
Moreover, mansion-like houses were built for officers. This building type had not been typical in this milieu up to that time. What is more, along with the hospital, the officers' estate gave rise to the construction of detached houses in the eastern part of the settlement, which had been full of orchards until then..$^{20}$ As a result, Berettyóújfalu took an important step forward in the area of urbanisation in the period.

After the Second World War, the Hungarian administrative system was reorganised. It was then that Hajdú-Bihar county was established, i.e. the former Hajdú and Bihar counties were merged. The new county seat became Debrecen, so Berettyóújfalu no longer held this role. On the other hand, in the era of state socialism, Berettyóújfalu was developed into a town playing a central role in the region. The latter, third period was the most important, as according to the principles of the socialist economy, considerable industrialisation took place in the settlement, which led to the appearance of residential buildings made by means of system-building technology in the downtown. The housing estates constructed in this period still determine the architectural identity of the town today.

The urban architectural results of these three periods are clearly observable in the current settlement. They constitute more zones of urbanisation, which are illustrated in our figure (Fig. 7). The first two periods (1867-1918, 1918-1944) are reflected by

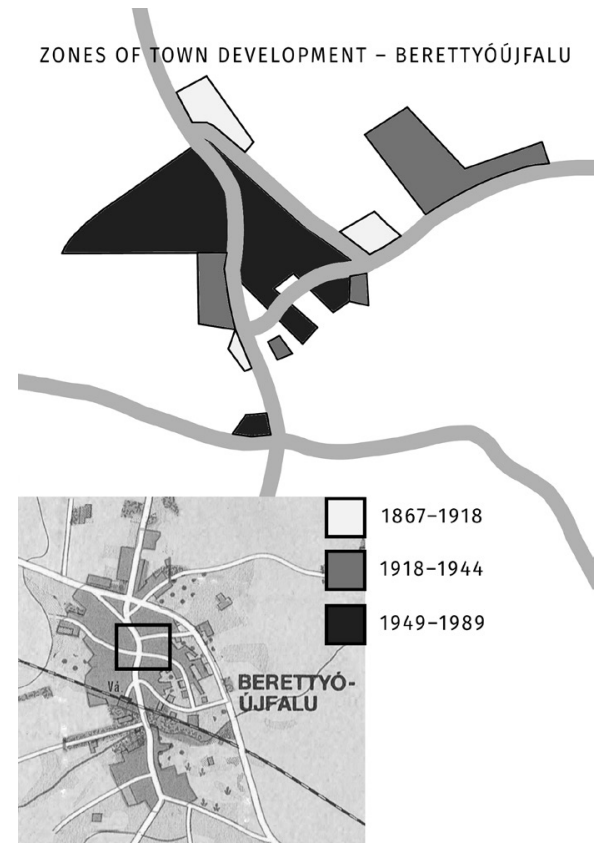

Figure 7. Zones of town development in Berettyóújfalu. Source: Berettyóújfalu. Térkép. Kartográfiai Vállalat, Budapest, 1988. Edited by: Megyeri-Pálffi, Z.

${ }^{20}$ Megyeri-Pálffi 2018. 31-59. 
spots today, while the third period of state socialism (1949-1989) appears as a more clearly defined, contiguous territory in the urban fabric.

In addition to the figure showing the zones of urbanisation, Table 1 helps us to compare the administrative and townscape changes of the city and the character of the periods.

Table 1. Comparing of the periods

\begin{tabular}{|l|l|l|l|l|l|l|}
\hline \multicolumn{2}{|l|}{ Periods } & $\begin{array}{l}\text { Administrative } \\
\text { status }\end{array}$ & $\begin{array}{l}\text { Character of admi- } \\
\text { nistrative institutions } \\
\text { public buildings }\end{array}$ & \begin{tabular}{l} 
Significant buildings \\
\cline { 4 - 6 }
\end{tabular} & $\begin{array}{l}\text { residential } \\
\text { buildings }\end{array}$ & $\begin{array}{l}\text { Scale of } \\
\text { towns- } \\
\text { cape } \\
\text { changes }\end{array}$ \\
\hline $\begin{array}{l}\text { Austro-Hungarian } \\
\text { Monarchy } \\
(1867-1918)\end{array}$ & 1871 & $\begin{array}{l}\text { municipality } \\
\text { district seat }\end{array}$ & $\begin{array}{l}\text { self-government and } \\
\text { state administration }\end{array}$ & $\begin{array}{l}\text { town hall } \\
(1875) \\
\text { district court } \\
(1913)\end{array}$ & + & \\
\hline $\begin{array}{l}\text { Between the two } \\
\text { world wars } \\
(1918-1944 / 1945)\end{array}$ & 1920 & $\begin{array}{l}\text { county seat } \\
\text { district seat } \\
\text { county seat }\end{array}$ & $\begin{array}{l}\text { self-government and } \\
\text { state administration }\end{array}$ & $\begin{array}{l}\text { county hall } \\
(1925) \\
\text { hospital }\end{array}$ & $\begin{array}{l}\text { civil ser- } \\
\text { vant estate }\end{array}$ & ++ \\
\hline $\begin{array}{l}\text { State socialism } \\
(1949-1989)\end{array}$ & 1950 & district seat & council (Soviet type) & $\begin{array}{l}\text { town hall } \\
(1983)\end{array}$ & $\begin{array}{l}\text { housing } \\
\text { estate }\end{array}$ & +++ \\
\hline
\end{tabular}

The political, economic, and social transformation accompanying the administrative changes also left an impression on the settlement in an architectural sense. The last three columns show the most important elements of this and the change in the townscape due to the new type of buildings in the settlement.

It can be clearly seen that in the age of the Austro-Hungarian Monarchy, although a kind of urban townscape began to emerge in Berettyóújfalu, only becoming a county seat brought about a greater change. This period is also surpassed - in a more quantitative sense - by the period of state socialism, in which the townscape was significantly transformed, mainly due to the housing estates built in the town centre. Therefore, our study focuses on this era.

\section{BERETTYÓÚJFALU IN THE ERA OF STATE SOCIALISM}

\section{THE ADMINISTRATIVE STATUS OF BERETTYÓÚJFALU IN THE ERA OF STATE SOCIALISM}

During the Second World War, the administrative status of Berettyóúffalu changed owing to the territorial changes in the country. The town lost its role as a county seat town in $1940 .{ }^{21}$ At the time, the county-level bodies moved back to Oradea, and Berettyóúffalu remained the capital of its district.

\footnotetext{
${ }^{21}$ Szikla 2014.
} 
After the Soviet military administration until 15 October 1944, sheriff dr. Sándor Zöld started the reorganisation of civilian administration in Berettyóújfalu. ${ }^{22}$

After the Second World War, the borders of 1939 were restored, therefore Berettyóújfalu became the seat of Bihar County again from the end of 1944 to 1950. In this period, offices were housed in the county hall, which had been built by 1925 , again..$^{23}$

In Hungary, the structure of public administration was altered owing to the political changes which had taken place by 1948 and the constitution of the people's republic of 1949, which laid down these changes. The introduction of the council system in the 1950s resulted in regional reorganisation, as well. The above-mentioned change in the division of public administration itself altered the status of certain settlements. Such changes also affected Bihar County, the seat of which had been Berettyóújfalu until then. In accordance with the Decree of the Interior Minister, Hajdú-Bihar County was born, including the whole former Hajdú County and Bihar County in $1950 .{ }^{24}$ As a result, the county seat status of Berettyóújfalu ceased again, but this time, instead of Oradea, Debrecen became its successor. Berettyóújfalu retained its status as a district town.

Besides, its classification in centralised urban development policy was favourable, as in the development plans of the 1950s, it was listed among the settlements of the first category. ${ }^{25}$ Berettyóújfalu was defined as an intermediate-level centre by the settlement network development concept of 1971.

Consequently, during the period of state socialism, the share of industry was considerably increased in the settlement (Fig. 8). In 1957, a milk powder factory was set up here. In 1975, the metal-goods factory (ELZETT) started operating, the nationalised Nyiri Mill was modernised, a clothing cooperative (clothing factory) was founded and the Tiszántúli Power Distribution Company (TITÁSZ) also established a site in the town. ${ }^{26}$ The factors above led to a significant increase in the population, mainly due to the people settling down in the town. In order to solve the problem of housing, large blocks of houses were built, resulting in the transformation of the settlement. This phenomenon will be detailed in our study later.

In this period, as far as administration is concerned, two important events took place in the life of Berettyóújfalu. One of them was the already mentioned union of the settlement with Berettyószentmárton in 1970. ${ }^{27}$ This move led to the growth of the urban body and an increase of the administrative region of the settlement.

\footnotetext{
${ }^{22}$ Gazdag 1981. 516.

${ }^{23}$ N. N. 2000. 3.

${ }^{24}$ Decree 5201/11/II-1/1950. (III. 12.) BM

${ }^{25}$ Jankovich 1950. 115.

${ }^{26}$ Bartha 2011. 72-73.

${ }^{27}$ Reg. 20/1970. NET
} 


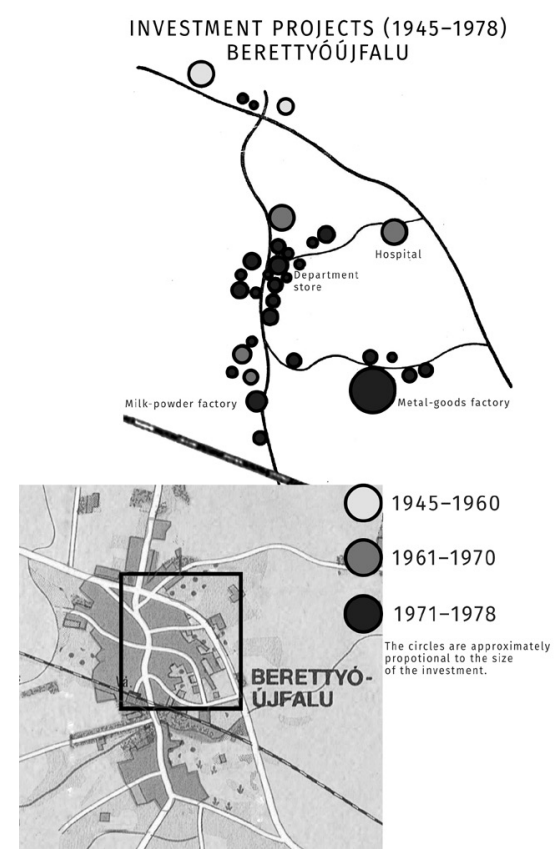

Figure 8. Investment projects in Berettyóújfalu (1945-1978). Source: Varga 1981. 573. Edited by: Megyeri-Pálffi, Z.

Therefore, Berettyóújfalu occupied both banks of the river it was named after. ${ }^{28}$ The other important event occurred at the end of the decade. As of 1 January 1979, Berettyóújfalu was awarded town rank..$^{29}$

\section{THE CHARACTER AND BUILDINGS OF ADMINISTRATIVE INSTITUTIONS IN BERETTYÓÚJFALU}

Even after the establishment of the council system, Berettyóújfalu remained in the legal status of municipality and district town. ${ }^{30}$ Similarly to other councils in the country, the council of the municipality was set up and started working in October 1950. The council elected an executive committee from its members, and then the standing committees were also set up in December, taking over the responsibilities of former bodies. ${ }^{31}$

\footnotetext{
${ }^{28}$ Gazdag 1976. 242.

${ }^{29}$ Reg. 19/1978. NET

${ }^{30}$ Decree 144/1950. (V. 20.) MT

${ }^{31}$ Gazdag 1976. 237-239.
} 


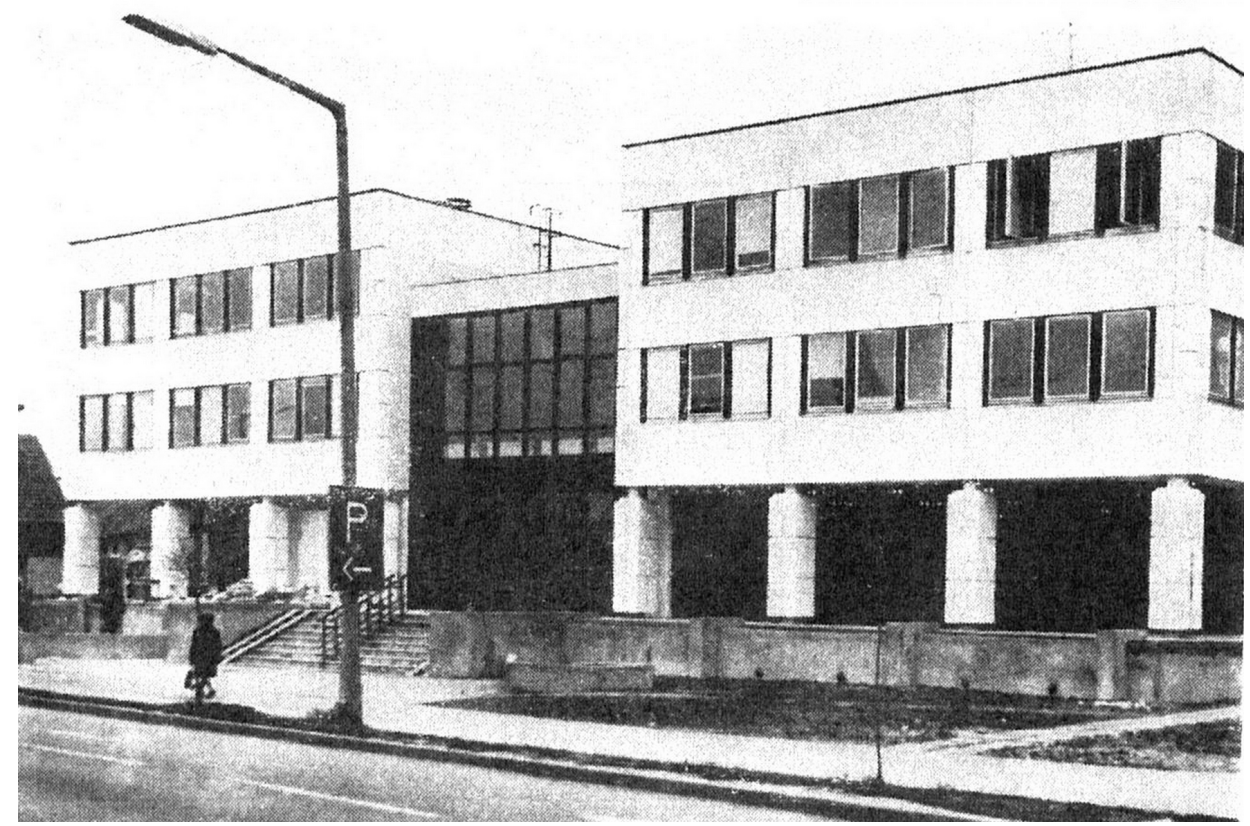

Figure 9. The building of the City Council of Berettyóújfalu and the National Bank of Hungary in 1983. Source: Kiss 1984. 73.

There is no accurate information available about in which building this council started working. Regarding the fate of the village hall, which was built in 1874-1875, it is known that after the Second World War, it functioned as the dormitory of a secondary school, and then it was the headquarters of the police until $1990 .{ }^{32}$ Subsequently, the building remained empty for many years. It was in 2001 when the still operating Bihari Museum moved there. Its photo collection reveals that the municipal council worked in two adjacent houses in Kossuth Street in the 1960s. These two houses existed even in the 1980s, until the completion of the new town hall in Berettyóúffalu.

The new headquarters was built in 1983. Following an old tradition, it housed not only the city council, i.e. public administration, but a branch of the National Bank of Hungary also moved to one of its bays. The framed panel building fitted into the circle of public buildings of the era and complied with the criteria specified by the contemporary urban planning concept, therefore it was considered to be a new construction in its close environment (Fig. 9). ${ }^{33}$

In addition to the village/town hall, the district offices were also moved to another place in the period of state socialism. After the town had lost its county seat status,

${ }^{32}$ Kállai 1992. 16.

${ }^{33}$ Kiss 1984. 73. 


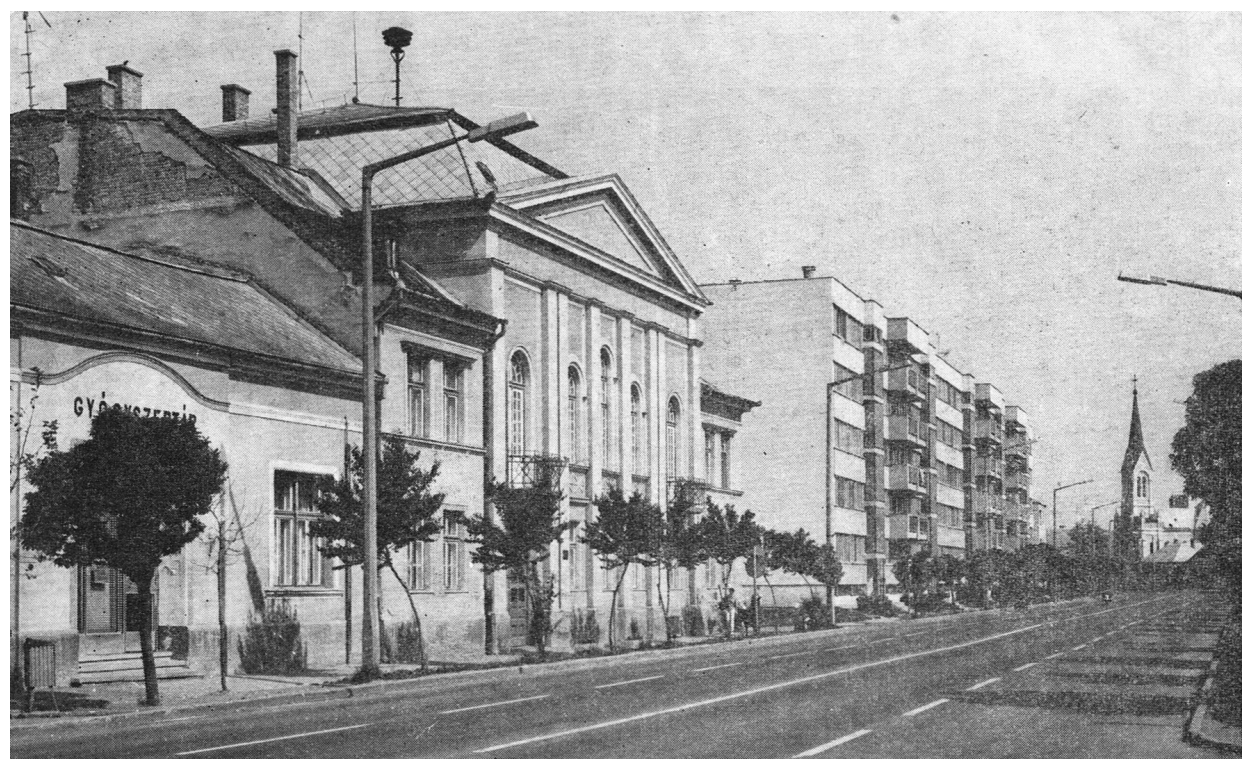

Figure 10. The former County Hall (later District Office) in the early 1980s. Source: Varga 1981. 669.

the county hall built between the two world wars could not be used for its original purpose anymore, but it was suitable for housing the district office. (Fig. 10)

A distinctive feature of the era was that beside party bodies, other bodies appeared, as well, doubling the size of the administrative structure. The importance of the party's role in operating the state is indicated by the fact that in several settlements, including Berettyóúfalu, special attention was paid to moving the party's organisation to a building that properly represented its significance. In Berettyóújfalu, the local headquarters of the party was housed in a new building, which had two storeys owing to its position and shape, though it was designed on the basis of a type design (Fig. 11). Our study also deals with this building, where the "party's administrative body" worked.

\section{THE CHANGE OF THE TOWNSCAPE IN BERETTYÓÚJFALU}

In Berettyóújfalu, the significant change of the townscape in the era of state socialism was mainly the result of the building of housing estates. The centrally managed development of the settlement, the establishment of industrial plants generated an increase in the number of new inhabitants, which necessitated the construction of a sufficient number of apartments. This process already started in the late 1960s. The location was directly in the downtown, behind the Calvinist church. Three squareshaped apartment blocks appeared. Their character was essentially different from that of previous residential buildings. 


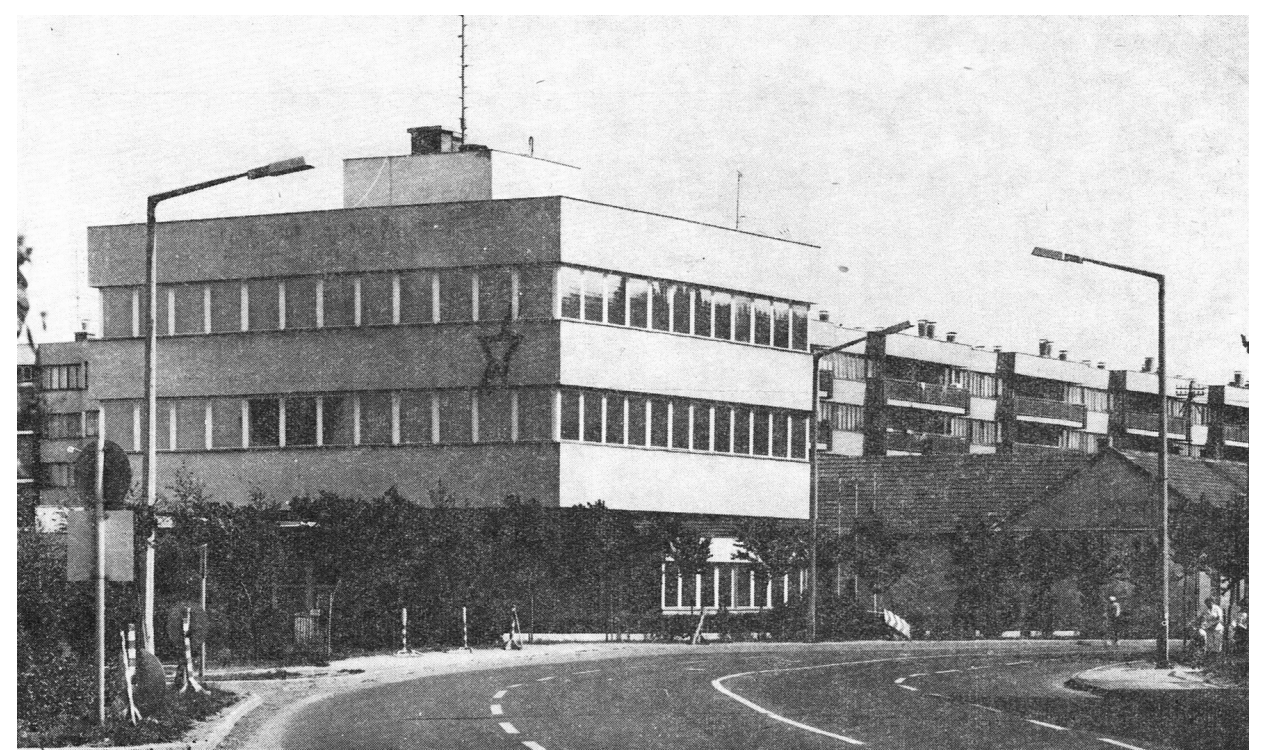

Figure 11. The party headquarters in the early 1980s. Source: Varga 1981. 676.

It was an intervention of smaller scale into the structure of the settlement. Similar examples can be found near the cultural centre (former paladins' house).

A system-building project of larger scale was represented by the two rows of panel residential buildings on the two sides of the main street and the adjacent edifices which formed an estate in the downtown. The establishment of the housing estate meant the destruction of the then fabric of the settlement. The organically developed small-townish central area was replaced by the new urban fabric reflecting the principles of modern urban design (Fig. 12).

As opposed to the construction projects generated by the settlement's becoming a county seat after the First World War, this change of architectural identity is in indirect relationship with the change in administrative status, as the construction of residential buildings from prefabricated components was the consequence of centralised urban policy.

The above-mentioned administrative buildings fitted well into the modern urban fabric consisting of housing estates. As we have already seen, the new town hall of the settlement was built at the time, obviously on the occasion of Berettyóúffalu's being awarded town rank in 1979. Due to the construction works of 1983, the administrative centre of the town moved to a completely new place, at least concerning the headquarters. This new location was in the main street, as well, but in a more southern area of it, which had belonged to the small-townish clustered urban fabric earlier. The location was at the intersection of several streets (Dózsa György, Bocskai, Csokonai), resulting in the formation of smaller squares. The aerial photographs from 

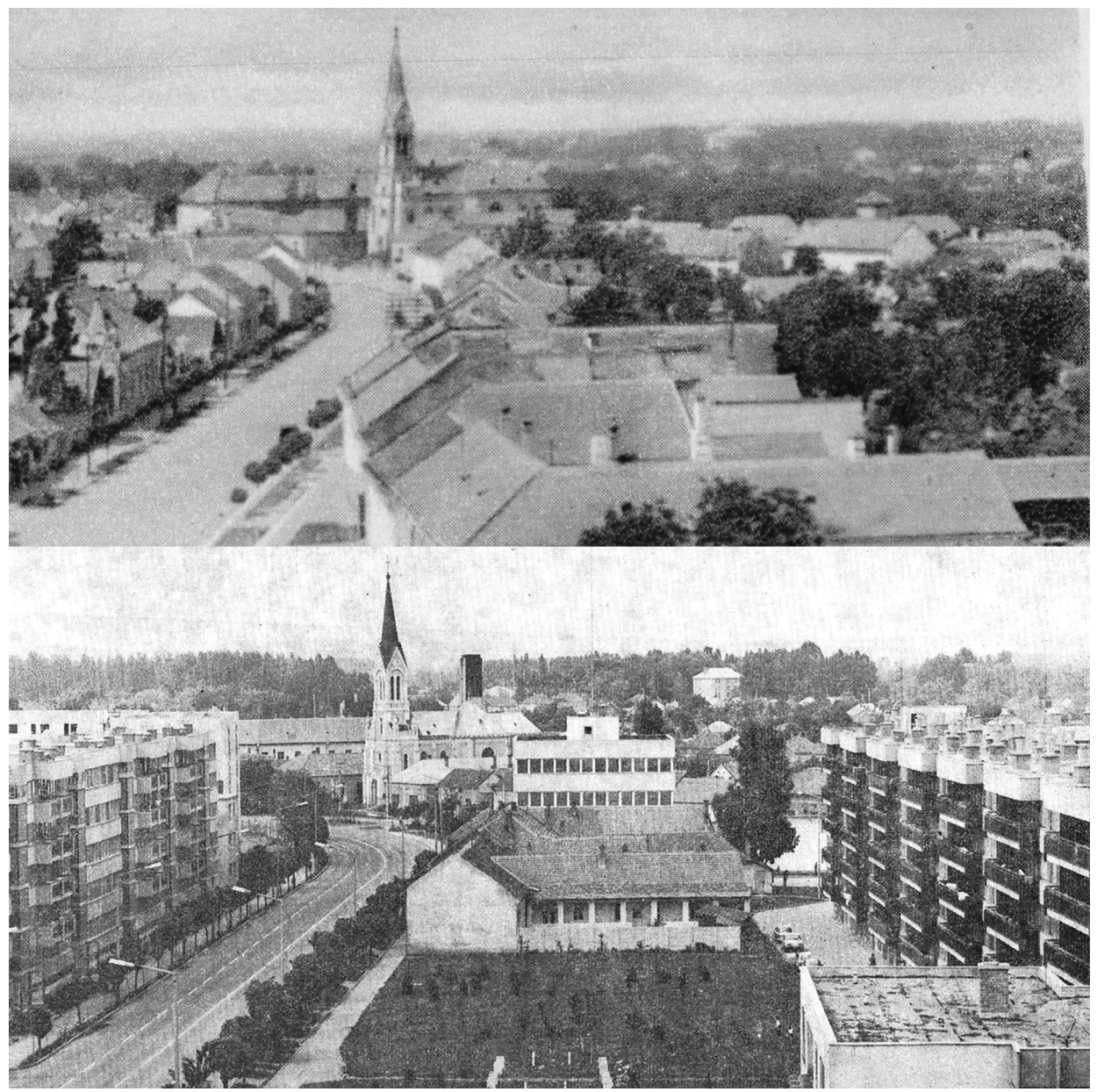

Figure 12. The changed view of Kossuth Street between the 1930s and 1980s. Source: Berettyóújfalu Topotéka, with the permission of Imre Békési (http://berettyoujfalu.topoteka.net), Bihari Múzeum, Berettyóújfalu; Varga 1981. 668. Edited by: Megyeri-Pálffi, Z.

1963 and 2009 clearly show that the town hall built in 1983 broke the former fabric of the settlement, as it was raised at the intersection of old streets (Fig. 13).

However, this square was not taken into consideration when the new town hall was constructed, as it was built directly on the square, following the building line of Elegance Department Store and a housing block, as a building complex fitting into the street line. Although its surroundings were landscaped and another part has been created on the other side of the main road, the new town does not have the central 


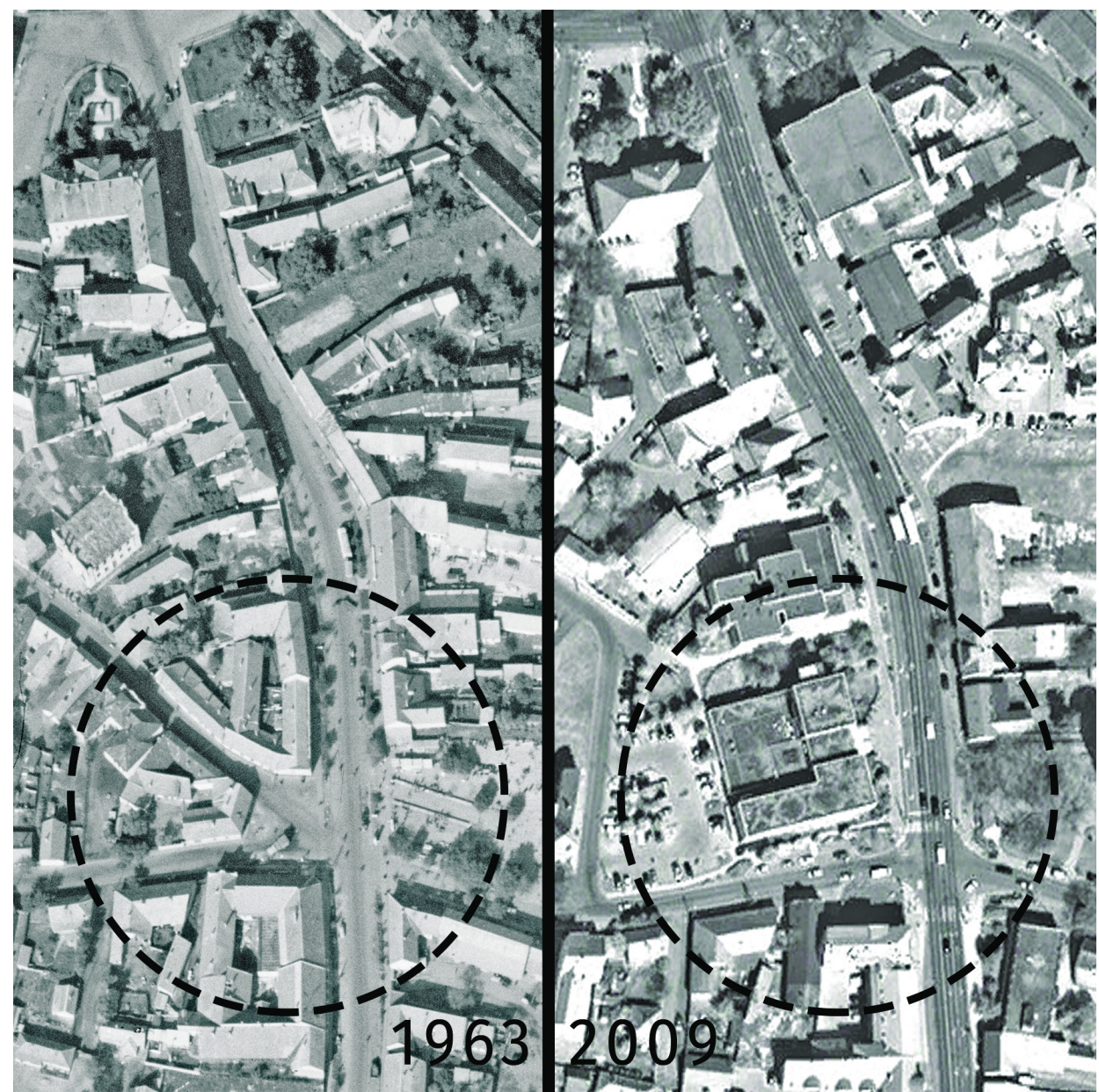

Figure 13. The location of the town hall (built in 1983) in the structure of the settlement. Source: fentrol.hu 1963-0177-4824, GoogleEarth 2009. Edited by: Megyeri-Pálffi, Z.

location the old town hall did. Regarding its character and function, it was rather an office building than a town hall.

Due to moving the town hall, the administrative zone along the main road was expanded. The northern point of this zone is still the district court built in 1912-1913, while it is closed by the town hall of the 1980s in the south.

Symbolically, the location of the party headquarters, which was also situated along the main street, was more fortunate. However, this building was raised at a point of the main street where two streets used to intersect. As a result, there used to be a square, it was the place where the main road used to bend towards the old town hall. 
The location of the new building is the counterpole to the old administrative headquarters, closing the major axis of the city centre. Its endpoint location took over the role of closing the city centre from the Catholic church built next to the district court in 1905, as the Calvinist church in the middle of the town and the Catholic church north of it used to be the two endpoints of the axis of the main street. The location of the party headquarters could even be of symbolic importance: as the counterpoint of the former bourgeois town hall, in contrast with the steeple, it opens the belt of residential buildings made with system-building technology of a modern town.

The architectural character of the centre of the settlement, which has developed in the way described above, has been virtually unchanged to date. However, the functions of the buildings became different after the change of regime: the former party headquarters was turned into a police station, the old village hall became a museum. Between these two poles, the manner in which the area has been built still reflects the principles of urban construction from both the 1920s-1930s and the 1970s-1980s. The barrenness of prefabricated buildings has been subdued by overgrowing vegetation, parks and playgrounds since the construction. Since 1989, tiny, pavilion-like shops appeared here and there between the blocks of the housing estate. In addition, garages have been converted and used for commercial purposes according to the space requirements of the already market-based service sector.

\section{SUMMARY}

Today, Berettyóújfalu's townscape is basically determined by three architectural periods: the era of the Austro-Hungarian Monarchy (1867-1918), the period between the two world wars (1918-1944) and the age of state socialism (1949-1989). Out of these periods, the third one was the most significant, as the most important interventions into the townscape occurred at that time. Regarding the above-mentioned periods and today's townscape, it seems that in Berettyóújfalu, the appearance of urban buildings has not been brought about by economic forces, but expressly by the change in the settlement's administrative status. It was this change that influenced the town's architectural character, which consists of two components: the official buildings and the residential building stock. In this case, both of them belong to the category of public construction projects. In the case of official buildings, it is reasonable, because new town halls were built due to the change in the settlement's administrative status in the 1870s and the 1980s. In the 1920, a county hall was raised for the same reason. In addition, several separate administrative buildings appeared in the town.

Residential buildings in the form of housing estates constitute another component of the building stock. The construction of housing estates falls into the category of public building projects, as after the Second World War, the system of state organisation changed fundamentally. Local governments ceased to exist, their role was taken over by hierarchical councils. Consequently, urban policy and urban construc- 
tion became central duties according to the socialist state concept. However, local conditions were not taken into consideration, therefore the townscape changed drastically.

The centrally developed industry and the resulting increase in the population was served by building housing blocks with system-building technology. These panel apartment blocks occupied the urban fabric that had been an integral part of the former townscape.

Interestingly, in the era of state socialism, construction projects did not destroy the most significant public buildings of previous periods. Despite losing their functions, the old multi-storey town hall, the county hall, the court, the school and the parish still exist, reminding us of the past. In the 1970s, a socialist small town with a lot of green areas was built around them. Perhaps today, these parks save the townscape, which has become a lovable architectural reader on Central and Eastern European history and urban development of the $19-20^{\text {th }}$ centuries.

\section{BIBLIOGRAPHY}

Antonič-Lazarevič 2019

Balla-Benkő-Durosaiye 2017

Barta 2017

Bartha 2011

Beluszky-Győri 2005

Benkő 2015

Benkő-Kissfazekas 2019
Antonič, Branislav - Lazarevič, Eva Vaništa: Decentralised Mass Housing Policy in Socialist Yugoslavia. In: Benkő, Melinda Kissfazekas, Kornélia (eds.): Understanding Post-Socialist European Cities. Case Studies in Urban Planning and Design. Éditions L'Harmattan, Budapest 2019. 172-187.

Balla, Regina - Benkő, Melinda - Durosaiye, Isaiah Oluremi: Mass Housing Estate Location in Relation to Its Liveability: Budapest Case Study. In: Eleni, Tracada - Graham, Cairms (eds.): Cities, Communities and Homes: Is the Urban Future Livable? Derby 2017. 192-203.

Barta, Attila: Közvetlen és közvetett közigazgatás. In: Balázs, István (ed.): Közigazgatás-elmélet. DUPress, Debrecen 2017. 53-78.

Bartha, Ákos: Élet Berettyóújfaluban a dualizmustól a rendszerváltozásig. In: Kállai, Irén (ed.): Berettyóújfalu az újkökortól napjainkig. Berettyóújfalu Önkormányzata, Berettyóújfalu 2011. 50-78.

Beluszky, Pál - Győri, Róbert: Magyar városhálózat a 20. század elején. Dialóg Campus, Budapest-Pécs 2005.

Benkő, Melinda: Budapest's Large Prefab Housing Estates: Urban Values of Yesterday, Today and Tomorrow. Hungarian Studies: A Journal of the International Association for Hungarian Studies and Balassi Institute 29 (2015) 1-2. 21-36.

Benkő, Melinda - Kissfazekas, Kornélia: Amoeba Cities: Towards Understanding Changes in the Post-Socialist European Physical Environment. In: Benkő, Melinda - Kissfazekas, Kornélia (eds.): Understanding Post-Socialist European Cities. Case Studies in Urban Planning and Design. Éditions L'Harmattan, Budapest 2019. 6-25. 
Berey 1994

Bonta 1986

Dankó 1981

ESPON 2012

Gazdag 1976

Gazdag 1981

Germuska 2002

Hajdú 1989

Hajdú 1990

Hirt 2007

Horák 2019

Iuga 2016

Jankovich 1950

Kállai 1992

Kiss 1984

Kissfazekas 2014

Kissfazekas 2015
Berey, Katalin: Housing Policy in Hungary. Periodica Polytechnica 2 (1994) 2. 85-95.

Bonta, János: Hungarian Architecture from 1960 to Now. Periodica Polytechnica Architecture 30 (1986) 1-4. 19-31.

Dankó, Imre: Berettyóújfalu kézmủvessége, árucsere viszonyai. In: Varga, Gyula (ed.): Berettyóújfalu története. Berettyóújfalu Városi Tanács, Berettyóújfalu 1981. 323-336.

ESPON Town. Small and Medium Sized Towns in Their Functional Territorial Context. Leuven 2012. Available at: https://www. espon.eu/sites/default/files/attachments/TOWN_Inception_ report_July_2012.pdf (Accessed 8 August 2019)

Gazdag, István (ed.): Helytörténetírás levéltári forrásai III. 1944-1971. (Hajdú-Bihar Megyei Levéltár Közleményei 9.) Hajdú-Bihar Megyei Levéltár, Debrecen 1976.

Gazdag, István: Berettyóújfalu a népi demokratikus forradalom időszakában. In: Varga, Gyula (ed.): Berettyóúffalu története. Berettyóújfalu Városi Tanács, Berettyóújfalu 1981. 515-527.

Germuska, Pál: A szocialista városok létrehozása. Századvég 2 (2002) 49-73.

Hajdú, Zoltán: Az első „szocialista” településhálózat-fejlesztési koncepció formálódása Magyarországon (1949-1951). Tér és Társadalom 3 (1989) 1. 86-96.

Hajdú, Zoltán: A településpolitika „szocialista” modelljének kialakítása Magyarországon (1949-1951). In: Tóth, József (ed.): Tér-Idö-Társadalom. MTA Regionális Kutatások Központja, Pécs 1990. 157-166.

Hirt, Sonia: The Compact versus the Dispersed City: History of Planning Ideas on Sofia's Urban Form. Journal of Planning History 6 (2007) 2. 138-165.

Horák, Peter: Bratislava's Changing Urban Fabric after World War II. In: Benkő, Melinda - Kissfazekas, Kornélia (eds.): Understanding Post-Socialist European Cities. Case Studies in Urban Planning and Design. Éditions L'Harmattan, Budapest 2019. 84-99.

Iuga, Liliana: Reshaping the Historic City under Socialism: State Preservaton, Urban Planning and the Politics of Scarcity in Romania (1945-1977). Dissertation, Central European University, Budapest 2016.

Jankovich, István: Magyarország funkcionális városhálózata. Budapest 1950. (script)

Kállai, Irén: Berettyóújfalu. Berettyóújfalu Város Önkormányzata, Berettyóújfalu 1992.

Kiss, Jenő: Tanácsház-MNB székház, Berettyóújfalu. Magyar Épitőipar 33 (1984) 1-2. 73.

Kissfazekas, Kornélia: Az államszocialista intézményegyüttesek városi kontextusa. Épités-Épitészettudomány 42 (2014) 1-2. 92132.

Kissfazekas, Kornélia: Relationships between Politics, Cities and Architecture Based on the Examples of Two Hungarian New Towns. Cities: The International Journal of Urban Policy and Planning 48 (2015) 99-108. 
Kissfazekas 2017

Körner-Nagy 2006

Megyeri-Pálffi 2017

Megyeri-Pálffi 2018

Meggyesi 2006

N. N. 1875

N. N. 2000

Sándor-Török 2011

Szikla 2014

Tandarić-Watkins-D. Ives 2019

Varga 1981

Węcławowicz 2016
Kissfazekas, Kornélia: Changes of Town Centres in the Era of State Socialism - Processes and Paradigms in Urban Design: Premeny mestských centier v ére štátneho socializmu - procesy a paradigmy $\mathrm{v}$ urbanistickom navrhovaní. Architektura and Urbanizmus 51 (2017) 1-2. 17-29.

Körner, Zsuzsa - Nagy, Márta: Az európai és a magyar telepszerü lakásépités története 1945-töl napjainkig. TERC, Budapest 2006. Megyeri-Pálffi, Zoltán: A Berettyóújfalui Járásbíróság épületének története. In: Megyeri-Pálffi, Zoltán (ed.): A jogszolgáltatás története Berettyóúffaluban. Debreceni Törvényszék, Debrecen, 2017. 57-67.

Megyeri-Pálffi, Zoltán: „Nagys. dr. Barcsay László kir. járásbíró úr lakóháza". Bihari Múzeum Évkönyve 23 (2018) 31-59.

Meggyesi, Tamás: Településfejlesztés. BME, Budapest 2006.

N. N.: Rombolják már a régi városház épületét. Biharmegyei Községi Értesitö (2 October 1875).

N. N.: 50 éve megszünt Berettyóújfalu megyeszékhely státusza. Bihari Hirlap (31 March 2000) 3.

Sándor, Mária - Török, Péter: Adatok Berettyóújfalu két világháború közötti infrastrukturális fejlődéséhez. In: Varjasi, Imre (ed.): Bihar vármegye a múló időben. Comitatul Bihor in timpul trecator. Hajdú-Bihar Megyei Levéltár, Debrecen 2011. 53-74.

Szikla, Gergő: Bihar és Hajdú vármegyék és Hajdú-Bihar megye közigazgatási beosztásának története 1850-2013. In: Szálkai, Tamás - Szikla, Gergő - Szilágyi, Ferenc: Bihar és Hajdú megye közigazgatásának története (1552-2013). Magyar Nemzeti Levéltár Hajdú-Bihar Megyei Levéltára, Debrecen 2014. (electronic edition)

Tandarić, Neven - Watkins, Charles - D. Ives, Christopher: Urban Planning in Socialist Croatia. HRVATSKI GEOGRAFSKI GLASNIK 81 (2019) 2. 5-41

Varga, Gyula (ed.): Berettyóújfalu története. Berettyóújfalu Városi Tanács, Berettyóújfalu, 1981.

Węcławowicz, Grzegorz: Urban Development in Poland, from the Socialist City to the Post-Socialist and Neoliberal City. In: Szirmai, Viktoria (ed.): "Artificial Towns" in the 21 $1^{\text {st }}$ Century. Social Polarisation in the New Town Regions of East-Central Europe. Budapest: Institute for Sociology. Centre for Social Sciences, Hungarian Academy of Sciences, Budapest, 2016. 6582. 


\title{
VÁLTOZÁSOK BERETTYÓÚJFALU KÖZIGAZGATÁSI HELYZETÉBEN ÉS VÁROSKÖZPONTJÁNAK BEÉPÍTÉSI FORMÁIBAN A MÁSODIK VILÁGHÁBORÚ UTÁN
}

\author{
Összefoglaló
}

A második világháború után Magyarország átvette az úgynevezett szovjet modellt, amely jelentős változásokhoz vezetett az államszervezetben. A „központosítás” és a „demokratikus centralizmus” azok a kulcsszavak, amelyek az állami szervek, s mellettük a helyi szervek müködését jellemezték az 1945 és 1990 közötti négy évtizedben.

Jelen tanulmány egy település városképének változásán keresztül arra világít rá, hogy Magyarországon - hasonlóan a többi volt szocialista államhoz - miként hatott a közigazgatási státus változása és a központilag meghatározott településpolitika a városépítészetre.

A mai Berettyóújfalu településképét alapvetően három építési periódus határozza meg: az OsztrákMagyar Monarchia kora (1867-1918), a két világháború közötti időszak (1918-1944) és az államszocializmus periódusa (1949-1989). Ezek közül a legmarkánsabb a harmadik, ugyanis ekkor történtek a legjelentősebb beavatkozások a településképben. E korszakokat és a mai városképet tekintve úgy tünik, hogy a városias épületek megjelenése Berettyóújfaluban nem a gazdasági erő hozadéka volt, hanem kifejezetten a közigazgatási helyzetének megváltozásáé. Ez befolyásolta igazán a mai építészeti karaktert, amelynek két összetevője van: egyrészt a hivatali, másrészt a lakóépület-állomány.

Az államszocializmusban a lakótelepek építése is a középítkezések körébe esik, miután a második világháború után alapvetően megváltozott az államszervezet rendszere. Az önkormányzatok megszűntek, helyüket a hierarchikusan müködő tanácsok vették át. Ennek velejárója volt, hogy a településpolitika, a városépítés központi feladattá vált a szocialista államfelfogásnak megfelelően.

A központilag meghatározott módon telepített ipart, a hozzá kapcsolódó lakosságnövekedést házgyári lakások felépítésével szolgálták ki. Ezek a paneles lakóházak épp azt a városszövetet foglalták el, amely egyébként a maga módján szervesen illeszkedett a korábbi városképbe.

Ilyen módon ez a megváltozott településkép egyfajta építészeti olvasókönyvévé vált a 19-20. század közép-kelet-európai történelmének és városépítészetének.

Kulcsszavak: közigazgatási helyzet, városképváltozás, szovjet modell, várostervezés, urbanizáció, Berettyóújfalu, Magyarország

Open Access statement. This is an open-access article distributed under the terms of the Creative Commons Attribution 4.0 International License (https://creativecommons.org/licenses/by/4.0/), which permits unrestricted use, distribution, and reproduction in any medium, provided the original author and source are credited, a link to the CC License is provided, and changes - if any - are indicated. (SID_1)

$\$$ Received: 9 April 2020. Accepted: 31 May 2020

First published online: 22 July 2020 
